\title{
REVIEW \\ Development of Rotary-type High Speed Puddling Harrow
}

\author{
Takashi GOTOH ${ }^{*}$, Mitsuhiro HORIO ${ }^{1}$, Tomohiko ICHIKAWA ${ }^{1}$, \\ Katsunari NAGAYA ${ }^{2}$ and Yoshiharu KUJI ${ }^{3}$ \\ ${ }^{1}$ Institute of Agricultural Machinery, Bio-oriented Technology Research Advancement Institution, \\ National Agriculture and Food Research Organization (Saitama, Saitama 331-8537, Japan) \\ 2 Kobashi Kogyo Co.,Ltd. (Okayama, Okayama 701-0292, Japan) \\ ${ }^{3}$ Sasaki Corporation (Towada, Aomori 034-8618, Japan)
}

\begin{abstract}
In order to improve the work rate of puddling, we developed rotary-type high speed puddling harrows. The stubble burying performance and the soil pulverizing performance of the developed puddling harrows were nearly the same as those of conventional puddling harrows working at 20 to $30 \%$ slower travel speeds. Power requirement of the developed puddling harrows were similar to those of conventional harrows. When the developed puddling harrows worked at 24 to $30 \%$ higher travel speeds than the conventional harrows, work rates of the developed puddling harrows were 21 to $22 \%$ larger, and the fuel consumption of the developed puddling harrows was 13 to $15 \%$ less than that of the conventional harrows.
\end{abstract}

Discipline: Agricultural machinery

Additional key words: power requirement, soil pulverizing, stubble burying, work rate

\section{Introduction}

In Japan, rotary harrows are a major equipment for puddling in paddy fields. Although the folding type puddling harrow which has wide working width has been developed, the work rate of puddling is still low ${ }^{5}$ because two or three repeated passes are necessary for accurate puddling. High speed puddling is also difficult because work accuracy such as stubble burying performance and soil pulverizing performance is reduced.

Based on this background, we developed rotary-type puddling harrows that had high performance on stubble burying and soil pulverizing, by installing new rakes in front of the rear cover and improving the arrangement of the blades. The developed puddling harrows have been commercialized and are widely utilized.

\section{Results of the fundamental tests}

We discussed the problems to be solved and the fac- tors related to high-speed puddling and then conducted fundamental tests on non-holding type puddling harrows. The following results were obtained ${ }^{1,2}$. (1) The stubble burying performance was improved by installing a large rake. The good average lateral clearance of the large rake teeth was 37 to $45 \mathrm{~mm}$. (2) It was better to adjust the mounting positions of the large rake according to the soil conditions. (3) The blade arrangement in which a pair of blades was installed $15 \mathrm{~mm}$ apart laterally yielded higher stubble burying and soil pulverizing performance than the conventional blade arrangement. (4) The PTO specific power of the harrow with rotary blades at a cutting angle of $95^{\circ}$ was 5 to $10 \%$ less than that of the harrow having $105^{\circ}$ cutting angle blades. However, the stubble burying performance of the $95^{\circ}$ cutting angle blades was worse than that of the $105^{\circ}$ cutting angle blades. (5) Increasing the blade rotating speed $8 \%$ improved the soil pulverizing performance slightly but degraded the stubble burying performance and increased the PTO specific power by $14 \%$.

\footnotetext{
* Corresponding author: e-mail takagoto@affrc.go.jp
}

Received 30 October 2009; accepted 25 January 2010. 


\section{Outline of the prototype puddling harrows}

Two prototypes of rotary-type high speed puddling harrows (Fig. 1) were manufactured ${ }^{2}$ based on the fundamental test results. The working widths of these machines were $2.4 \mathrm{~m}$ for the non-folding type and $3.0 \mathrm{~m}$ for the folding type. The rotary blades were the same as those of conventional harrows, the cutting angles of which were $105^{\circ}$ for the non-folding type and $88^{\circ}$ for the folding type (Table 1).

These puddling harrows had the following features. (1) New large rakes were installed in front of the rear cover (Fig. 2). The lateral clearance of large rakes was 37 $\mathrm{mm}$ for the non-folding type and $42 \mathrm{~mm}$ for the folding type. The mounting position of the large rakes could be adjusted according to the soil conditions. (2) The lateral arrangement of the blades was changed (a pair of blades was installed $15 \mathrm{~mm}$ apart laterally) in the non-folding type (Fig. 3). (3) The inner volume of the rear cover was larger than that of conventional harrows.

\section{Working performance}

\section{Work accuracy and power requirement}

Two prototypes of rotary-type high speed puddling harrows and two conventional rotary-type puddling harrows were employed to investigate the accuracy of puddling in six paddy fields (soil texture: $\mathrm{LS}, \mathrm{L}$ and $\mathrm{SiC}$ ) and

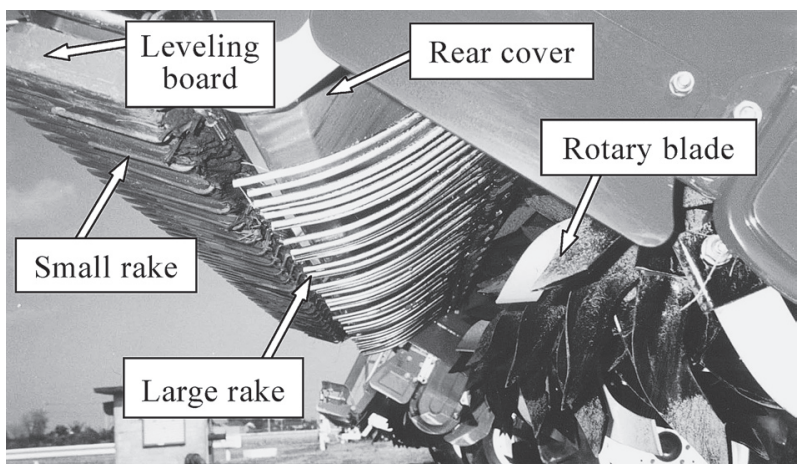

Fig. 2. Construction of high speed puddling harrow

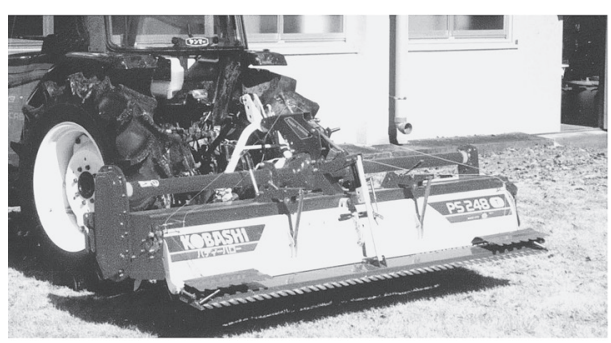

a) Non-folding type
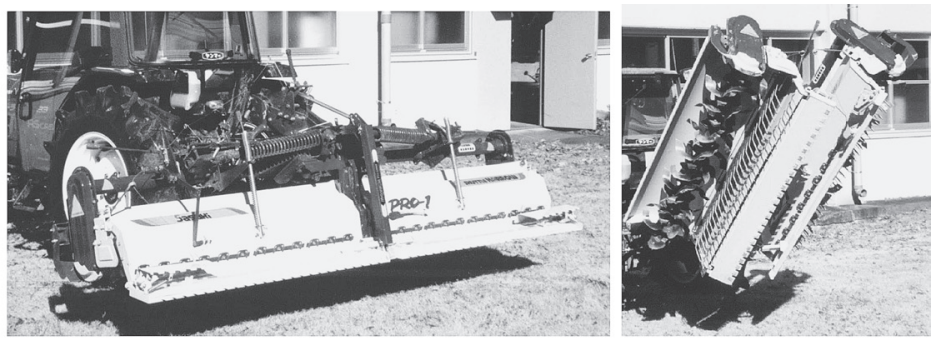

b) Folding type

Fig. 1. Prototype of high speed puddling harrows

Table 1. Specifications of developed and conventional paddling harrows

\begin{tabular}{|c|c|c|c|c|c|}
\hline \multicolumn{2}{|c|}{ Kind of machines } & \multicolumn{2}{|c|}{ Non-folding type } & \multicolumn{2}{|c|}{ Folding type } \\
\hline & & Developed & Conventional & Developed & Conventional \\
\hline \multirow{3}{*}{\multicolumn{2}{|c|}{$\begin{array}{l}\text { Working width }(\mathrm{m}) \\
\text { Total mass }(\mathrm{kg}) \\
\text { Adaptable tractor }(\mathrm{kW})\end{array}$}} & 2.4 & 2.4 & 3.0 & 3.0 \\
\hline & & 309 & 293 & 410 & 425 \\
\hline & & $18-34$ & $18-34$ & $24-46$ & $24-46$ \\
\hline \multirow{4}{*}{ Blade } & Number of blades & 64 & 64 & 80 & 80 \\
\hline & Lateral installing interval $(\mathrm{mm})$ & 60 or 15 & 75.5 & 72 & 72 \\
\hline & Rotational radius $(\mathrm{mm})$ & 185 & 185 & 180 & 180 \\
\hline & Cutting width (mm) & 46 & 46 & 55 & 55 \\
\hline \multirow{3}{*}{ Large rake } & Diameter of rods (mm) & 6 & - & 8 & - \\
\hline & Average pitch (mm) & 42 & - & 50 & - \\
\hline & Average lateral clearance $(\mathrm{mm})$ & 37 & - & 42 & - \\
\hline \multirow{2}{*}{ Small rake } & Diameter of rods (mm) & 4 & 4 & 4 & 4 \\
\hline & Average pitch (mm) & 100 & 100 & 60 & 60 \\
\hline
\end{tabular}


power requirement in four paddy fields (soil texture: LS and $\mathrm{SiC})^{3}$. The following results were obtained. (1) The stubble burying performance and the soil pulverizing performance of the developed puddling harrows exceeded that of the conventional harrows at the same travel speed as the developed puddling harrows (Figs. 4 and 5). (2) The stubble burying performance and the soil pulverizing performance of the developed puddling harrows were nearly the same as those of conventional harrows working at 20 to $30 \%$ slower travel speeds (Figs. 4 and 5). (3) The stubble burying performance and the soil pulverizing performance of the developed puddling harrows after two passes were almost equal to those of the conventional harrows at the same travel speed after three passes. (4) The average PTO specific power of the developed puddling harrows was almost equal to that of the conventional harrows in the primary puddling and the final puddling.

\section{Work rate and fuel consumption}

Two prototypes of rotary-type high speed puddling

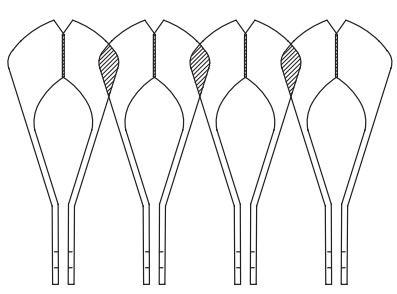

a) Non-folding type

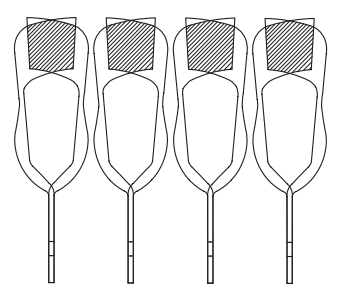

b) Folding type
Hatching part: Second time cutting per rotation

Fig. 3. Lateral disposition of rotary blades

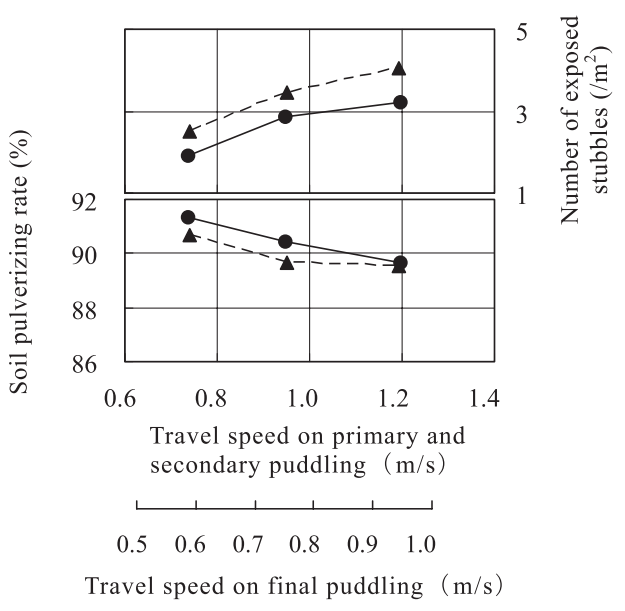

Fig. 4. Work accuracy of non-folding type paddling harrow (mean value of the tests in four fields)

: Developed harrow, $\boldsymbol{\Delta}$ : Conventional harrow. harrows and two conventional rotary-type puddling harrows were employed to investigate the work rate and the fuel consumption in a SiC paddy field ${ }^{4}$. When the developed puddling harrows worked at 24 to $30 \%$ higher travel speeds than the conventional harrows, work rates of the developed puddling harrows were 21 to $22 \%$ larger, and the fuel consumption of the developed puddling harrows were 13 to $15 \%$ less than that of the conventional harrows (Table 2).

\section{Influence of high speed puddling on rice transplanting}

Two prototypes of rotary-type high speed puddling harrows and two conventional rotary-type puddling harrows were employed to investigate the accuracy of rice transplanting after puddling in two paddy fields (soil texture: $\mathrm{SL}$ and $\mathrm{SiC})^{4}$, and the following results were obtained (Table 3). (1) The amount of exposed stubble after puddling and the rate of surfaced- and buried-seedlings after rice transplanting produced by the developed puddling harrows operating at the same travel speed as the conventional harrows were fewer than those produced by the conventional harrows. (2) The accuracy of puddling and rice transplanting that was produced by the developed puddling harrows operating at 20 to $30 \%$ higher travel speeds, and at one less pass than the conventional harrows was nearly the same as that produced by the conventional harrows.

\section{Conclusion}

The developed rotary-type high speed puddling harrows were more accurate for stubble burying and soil pul-

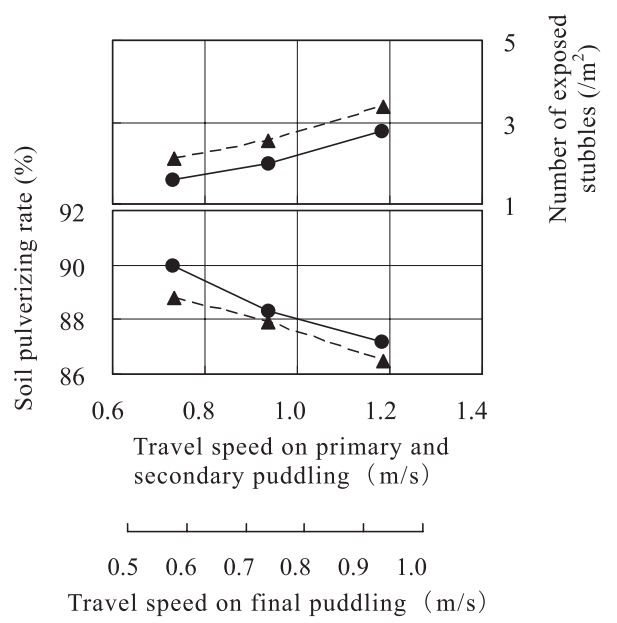

Fig. 5. Work accuracy of folding type paddling harrow (mean value of the tests in four fields)

: Developed harrow, $\boldsymbol{\Delta}$ : Conventional harrow. 
Table 2. Work rate and fuel consumption

\begin{tabular}{|c|c|c|c|c|c|}
\hline \multicolumn{2}{|l|}{ Experimental plot } & \multicolumn{2}{|c|}{ Non-folding type } & \multicolumn{2}{|c|}{ Folding type } \\
\hline & & Developed & Conventional & Developed & Conventional \\
\hline \multirow{3}{*}{ Travel speed $(\mathrm{m} / \mathrm{s})$} & Primary puddling & 0.79 & 0.65 & 0.81 & 0.65 \\
\hline & Secondary puddling & 0.79 & 0.66 & 0.82 & 0.66 \\
\hline & Final puddling & 0.66 & 0.51 & 0.66 & 0.47 \\
\hline \multicolumn{2}{|l|}{ Work rate $(\mathrm{a} / \mathrm{h})$} & 16.3 & 13.5 & 20.3 & 16.6 \\
\hline \multicolumn{2}{|c|}{ Fuel consumption (L/ha) } & 33 & 39 & 26 & 30 \\
\hline
\end{tabular}

Table 3. Work accuracy of rice transplanting (mean value of the tests in two fields)

\begin{tabular}{|c|c|c|c|c|c|}
\hline \multicolumn{2}{|c|}{ Experimental plot } & \multicolumn{3}{|c|}{ Developed harrow } & \multirow{2}{*}{$\begin{array}{c}\text { Conventional } \\
\text { harrow } \\
2 \text { or } 3 \text { passes }\end{array}$} \\
\hline & & $\begin{array}{l}\text { High speed } \\
2 \text { or } 3 \text { passes }\end{array}$ & $\begin{array}{l}\text { Same speed } \\
2 \text { or } 3 \text { passes }\end{array}$ & $\begin{array}{l}\text { Same speed } \\
1 \text { or } 2 \text { passes }\end{array}$ & \\
\hline \multirow{3}{*}{$\begin{array}{l}\text { Travel speed of } \\
\text { harrows }(\mathrm{m} / \mathrm{s})\end{array}$} & Primary puddling & 0.89 & 0.70 & $0.62^{1)}$ & 0.70 \\
\hline & Secondary puddling & $0.78^{1)}$ & $0.62^{1)}$ & - & $0.63^{1)}$ \\
\hline & Final puddling & 0.72 & 0.57 & 0.56 & 0.56 \\
\hline \multicolumn{2}{|c|}{ Number of exposed stubbles ${ }^{2}\left(/ \mathrm{m}^{2}\right)$} & $4.1^{\mathrm{a}}$ & $3.2^{\mathrm{b}}$ & $4.7^{\mathrm{a}}$ & $4.4^{\mathrm{a}}$ \\
\hline \multicolumn{2}{|c|}{ Soil pulverizing rate $(\%)$} & $88^{\mathrm{a}}$ & $89^{\mathrm{a}}$ & $87^{\mathrm{a}}$ & $90^{\mathrm{a}}$ \\
\hline \multicolumn{2}{|c|}{ Travel speed of rice transplanter $(\mathrm{m} / \mathrm{s})$} & \multicolumn{4}{|c|}{$0.8 \sim 1.0$} \\
\hline \multicolumn{2}{|c|}{ Planting depth ${ }^{2)}(\mathrm{cm})$} & $3.1^{\mathrm{a}}$ & $3.1^{\mathrm{a}}$ & $2.8^{\mathrm{b}}$ & $2.8^{\mathrm{b}}$ \\
\hline \multicolumn{2}{|c|}{ Surfaced seedling rates $(\%)$} & $0.24^{\mathrm{a}}$ & $0.19^{\mathrm{a}}$ & $0.21^{\mathrm{a}}$ & $0.26^{\mathrm{a}}$ \\
\hline \multicolumn{2}{|c|}{ Buried seedling rates ${ }^{2}(\%)$} & $0.16^{\mathrm{ab}}$ & $0.07^{\mathrm{a}}$ & $0.08^{\mathrm{a}}$ & $0.20^{\mathrm{b}}$ \\
\hline \multicolumn{2}{|c|}{ Inclined seedling rates $(\%)$} & $0.91^{\mathrm{a}}$ & $0.76^{\mathrm{a}}$ & $0.75^{\mathrm{a}}$ & $0.76^{\mathrm{a}}$ \\
\hline
\end{tabular}

1): Data in one field.

2): $5 \%$ significant difference between a and $b$.

verizing than conventional models. Power requirements of the developed puddling harrows were similar to those of conventional models. As a result, even when the travel speed was increased, the performance of the developed puddling harrows was still similar to that of conventional models with a higher work rate and less fuel consumption.

We now expect to manage larger work areas more timely, reduce energy consumption and provide comfortable work by using the developed rotary-type puddling harrows. Rotary-type high speed puddling harrows have been sold since 2002, and three companies had manufactured 63,000 machines by Mar. 2010. The development of these machines has promoted highly efficient puddling work in paddy fields.

\section{Acknowledgments}

This work was supported by the Project of Urgent
Development of Agricultural Machinery from the Ministry of Agriculture, Forestry and Fisheries, Japan.

\section{References}

1. Gotoh, T. et al. (2005) Development of high-speed rotary harrow for puddling (Part 1). J. JSAM, 67(1), 97-104 [In Japanese with English summary].

2. Gotoh, T. et al. (2005) Development of high-speed rotary harrow for puddling (Part 2). J. JSAM, 67(1), 105-114 [In Japanese with English summary].

3. Gotoh, T. et al. (2005) Development of high-speed rotary harrow for puddling (Part 3). J. JSAM, 67(1), 115-123 [In Japanese with English summary].

4. Gotoh, T. et al. (2005) Development of high-speed rotary harrow for puddling (Part 4). J. JSAM, 67(2), 121-129 [In Japanese with English summary].

5. Nishimura, Y. et al. (1997) Studies on large scale farm mechanization system (Part 1). Japanese Journal of Farm Work Res., 34 Extra Issue 1, 37-38 [In Japanese]. 